\title{
PRESERVATION OF THE ENVIRONMENT BY SMART ENERGY CONSUMPTION
}

\author{
Shahino Mah Abdullah*
}

\begin{abstract}
The rise in world energy consumption has caused an alarming shortage of fossil fuels and an increase in carbon emissions. It has also led to various environmental issues, especially climate change, which threaten humanity's access to food, water, shelter, energy and health. The growth of the human population combined with rapid development has caused excessive carbon emissions, while the conventional ways of energy production and utilisation need serious reconsideration. This article, therefore, draws attention to the vital role that human beings, as vicegerents of the Earth (khalifah), have in managing natural resources. It highlights the pivotal position of humans in the world, as trustees who bear great responsibility for maintaining the natural environment. At the same time, this article also draws attention to the Islamic concept of moderation (wasatiyyah) and its practice to improve the consumption of resources by reducing wastage and pollution. The concept of moderation in the context of consuming natural resources is generally supported by the advancements in maqasid al-shari 'ah (higher objectives of Islamic law) that have included the significance of environmental preservation (hifz al-bi 'ah). This article also seeks to inform the development of Renewable Energy (RE) in the context of the Islamic concern for inclusive well-being. Several policy actions capable of promoting the concept of $i$ 'mar al-ard (building of the Earth) and smart energy consumption are proposed to address environmental issues in our policy recommendations towards the end.
\end{abstract}

Keywords: preservation of environment, smart energy consumption, energy mix, renewable energy, climate change.

\section{Introduction}

In nature, sunlight and water are needed by plants to drive photosynthesis for growth. This process turns light into chemical energy which later fuels a plant's activities. However, warm sunlight and nutrient-rich soil are not the only components that enable life. The intake of atmospheric gas, such as carbon dioxide, is also one of the vital processes for respiration that keeps plants alive. These life processes briefly describe the basic needs of all living things (including human beings) that are reliant on the sun's energy, ambient air, nutritious foods and water. 
For humans, these resources can also be used to generate energy. Plants and trees, in general, are commonly treated by humans as sources of food, remedies, and shelter. They can also be turned into a source of energy, such as when the friction between wooden sticks is used to light up a fire pit for cooking and, at the same time, used to overcome cold weather at night. Water, on the other hand, is not only for drinking and preparing meals; it has also been utilised as a source of energy to facilitate daily work through the invention of the watermill. Moreover, energy can also be generated from atmospheric air as it blows strongly on a windy day. The wind energy captured by windmills can do similar work to the watermill, grinding grain and pumping water. The usage of these resources significantly assists, simplifies, and expedites human activities without compromising the environmental aspect. However, demand for various natural resources, including energy, starts to increase as the human population keeps growing. ${ }^{1}$

Over the past centuries, human exploration for new resources has led to the discovery of fossil fuels, such as coal, natural gas, and petroleum. Advancement in technological innovations have made these resources the best type of fuel for powering heavy machinery. This early success was backed up by the crucial role of water, utilised in steam turbines and engines for generating electricity, expanding transportation routes and empowering hydraulic systems. Eventually, the increase in energy production drove rapid industrial development, including the world's industrial revolutions. As a result, world energy consumption was increased while natural resources were depleted. ${ }^{2}$ The current shortage of fossil fuels and increase in carbon emissions is extremely alarming. ${ }^{3,4}$ The problem arises when the growth of development outstrips the growth of supplies from the environment. Unfortunately, resources are not used to fulfil the needs of human beings as a whole but merely exploited to fulfil profitable interests by any means, including compromising nature.

For this reason, the consumption of natural resources must be set right and made smarter. Therefore, this article draws attention to the vital role of human beings in managing natural resources, not only as consumers but also as vicegerents of the Earth (khalifah). It also highlights the position of humans in the world, not only as beneficiaries, but also as trustees who bear great responsibility to manage and safeguard the Earth. First, the article will discuss the preservation of the environment from an Islamic perspective, linking it to the maqasid al-shari 'ah (higher objective of Islamic law) discourse. Then the article will highlight the challenges of rising energy consumption, including recent environmental issues. In this context, the author will also mention Malaysia's green initiatives, intended to help the people by promoting the use of green technology in preserving the environment. Finally, the author will share his thoughts on smart energy strategies 
for sustainable development and on the future of Renewable Energy. A set of recommendations is then listed towards an end.

\section{Preservation of the Environment from an Islamic Perspective}

Islamic teachings address the human-Earth relationship through a set of principles, namely tawhid (divine oneness), khalifah (vicegerency of man), and amanah (trusteeship). The principle of tawhid is manifested in the unity of God's creation, which includes men, women and the whole universe that exists in balance. It also means that human beings are part of a natural equilibrium that must not be violated. The principle of khalifah implies that humans hold a position of power, trust and responsibility to develop the Earth. It also entails a human responsibility to safeguard the rights of fellow humans, nature and other inhabitants of the Earth. The principle of amanah, as an essential part of the faith of a Muslim, highlights the entrusted role of humanity as custodian on the Earth. ${ }^{5}$ While the most important of all amanat is justice ( $a d l$ ), the doing of good (ihsan) towards fellow human beings and the natural environment is also important. This means humankind has to take good care of what it owns and uses, both for its own benefit and for that of the community and the environment at large. Preserving the balance (mizan) entails that benefiting from natural resources should not be achieved at the expense of the environment. Further, these principles lead to the concept of $i$ 'mar al-ard (building of the Earth) that encourages human progress in developing the Earth while preserving environmental well-being. ${ }^{6}$

As mentioned, in the Qur'an Allah (SWT) commands human beings to guide themselves from mischief on the Earth: "And do not cause corruption on the Earth after its restoration. That is better for you, if you are faithful" (Q. al-A'raf, 7:85). In another verse: "Be good [to others] just as Allah has been good to you, and do not try to cause corruption in the land. Indeed, Allah does not like the agents of corruption" (Q. al-Qasas 28:77). In general, these exhortations refer to all types of possible corruption, including wasting the Earth's resources, as doing so can lead to the destruction of the environment. Based on these strong exhortations, it is made clear that we must be considerate and take good care of the environment in order to maintain its natural balance. This measure should ultimately begin from the individual-level, via correct understanding and deep awareness.

According to renowned Islamic jurisprudence scholar Mohammad Hashim Kamali, the Qur'an and hadith make trust (amanah) an integral part of the faith of a Muslim. The Qur'an, for example, says a faithful Muslim will "fulfil their trusts (amanat) and observe their promises and commitments" (Q. al-Mu'minun 23:8). Therefore, it can be understood that those who believe in Allah will surely 
take good care of the trust (amanah) given to them. One important trust is safeguarding the environment and avoiding mischief towards it. In this context, the conservation of the balance of the ecosystem is in line with the order to avoid corruption on Earth. A progressive approach known as 'green energy practices' can be adopted to protect the Earth's environment, and should first and foremost nurture Islamic values in human morals. The implementation of green energy practices for the sake of human and environmental well-being can be achieved by spreading public awareness, group cooperation, outlining strict enforcement, and continuous monitoring of activities.

Moreover, these practices are actually in line with the Islamic teaching to be moderate (wasatiyyah) in the use of resources, to be assiduous in their use and avoid extravagance. Islam forbids extravagance, including the excessive use of water. Prophet Muhammad (PBUH) once said to his companion Sa'ad, who was performing his wudu (ablution): "Water should not be wasted when making ablution even if you are by a flowing river" (narrated by Ibn Majah). It is our challenge, and not only that of the government, to address the issue of wastage and increasing energy consumption. Self-awareness and timely initiative through 'energy efficiency' implementation plays an important role in conserving existing resources for future generations.

\section{Rise of Energy Consumption}

In this paper, increasing world energy consumption is highlighted as the main cause of multiple environmental issues. The growth of the human population is one of the factors causing increased energy consumption. According to a United Nation Department of Economic and Social Affairs (UN DESA) report, the current world population of 7.6 billion is projected to increase by 1 billion over the next ten years and reach 9.6 billion by $2050 .{ }^{7}$ Unfortunately, access to humanity's main source of energy, electricity, is still limited. Indeed, there are groups of people with no access to electricity at all, such as in Africa (57 percent), Asia (17 percent), the Middle East (8 percent), and Latin America (5 percent). ${ }^{8}$ As of 2016, there were 1.06 billion people (14 percent of the world population) with no access to electricity, a figure expected to reduce to 674 million ( 8 percent of the world population) by 2030, 90 percent of whom will live in rural areas. ${ }^{9}$ Provision of electricity for an additional 674 million people will require an extra investment of some $\$ 391$ billion, going towards decentralising power systems, upgrading the on-grid transmission-and-distribution networks, and building new grid-connected generation plants.

Besides increases in population, standards of living for many people in developing countries have also increased, which in turn results in a significant growth in energy demand. In this sense, the increase in energy demand is also 
attributed to the rapid progress of human civilisation in developing the world we live in. As a developing country, Malaysia is not immune to this growing energy demand. Electricity is a crucial form of energy that has driven Malaysia's economy and development for more than a century. The first use of electricity in Malaya was in 1894, when the enterprising individuals Loke Yew and Thamboosany Pillai installed a power generator at Rawang, Selangor, to operate the electric pump in their mines. The electricity from this generator was later extended to Rawang town for the street lighting. During the following year, Kuala Lumpur's railway station received its first electricity. Later, in 1900, the Raub Australian Gold Mining Company established the first power station in Malaya, known as Sempam Hydroelectric Power Station, located in Raub, Pahang. This marked the beginning of electricity distribution in Malaya, as well as the rise of energy demand throughout Malaysia.

Recently, the Malaysian Energy Commission reported that energy consumption in Malaysia is showing an increasing trend year-by-year. This growing trend not only impacts the environment but also incurs great cost for Malaysia, which relies heavily on fossil fuels. It was reported on 1 April 2017 that Malaysia's power generation industry spent RM15.1 billion to generate 120,059 Gigawatt-hours (GWh) of electricity for 8.45 million customers in Peninsular Malaysia. ${ }^{10}$ To get a clearer picture of fossil fuel dependency, the International Energy Agency, in their 'World Energy Outlook 2007', stated that in the run up to 2030, global energy needs are expected to grow, with fossil fuels remaining the dominant resource. ${ }^{11}$ In order to reduce this fossil fuel dependency, the energy mix strategy has emerged as a smart alternative measure to face the shortage of conventional fossil fuels. In other countries that have already started to harvest energy from alternative resources, like the UK for example, energy consumption has been successfully reduced, with current usage being less than what it was in the 1970s, despite an extra 6.5 million people living there. ${ }^{12}$ In Malaysia, this energy mix strategy has successfully reduced oil dependency from 87 percent in 1980 to less than 1 percent today. However, since the energy mix is only based on other fossil fuels, dependency on coal and natural gas has increased to 87 percent for both, while less than 10 percent of energy comes from hydroelectric. ${ }^{13}$

Malaysia's power stations utilise various resources to generate electricity, which is then distributed throughout the country. Figure 1 shows the major power stations in Peninsular Malaysia currently operated and owned by Tenaga Nasional Berhad (TNB) through its Transmission Division. The figure shows existing thermal and hydropower systems in Peninsular Malaysia by triangle and square indications, respectively. There are two other electrical grid systems in Sabah and Sarawak, shown in Figure 2, operated by Sabah Electricity Sdn. Bhd. 
(SESB) and Sarawak Electricity Supply Corporation (SESCO), respectively. Overall, most energy production in Malaysia is generated from thermal power, by burning coal and natural gas. The system spans the whole country, connecting electricity generation stations mostly owned by TNB and some Independent Power Producers (IPPs) to energy consumers. ${ }^{14}$ IPPs are non-public entities (e.g. YTL Corp, Genting Sanyen and Malakoff) who own facilities for generating electric power that is then sold to either power utility companies or directly to end users.

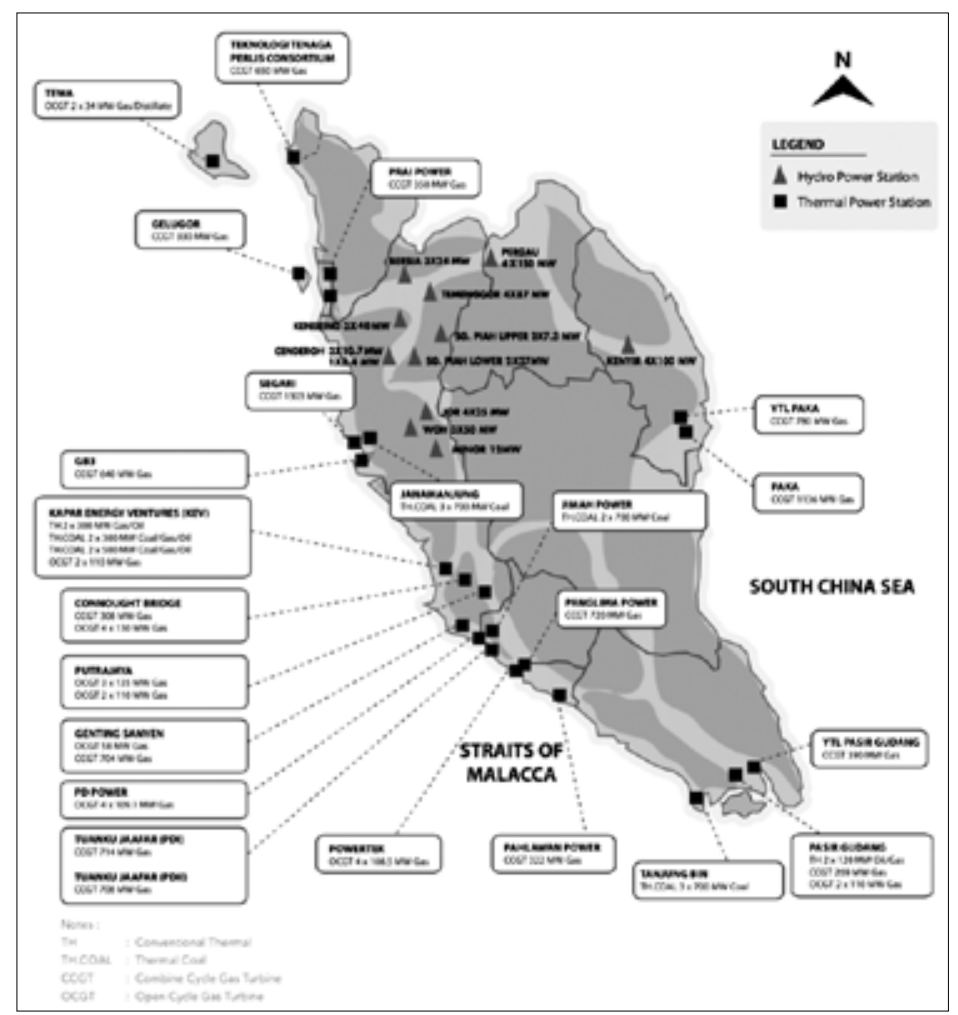

Figure 1: Major power stations in Peninsular Malaysia 


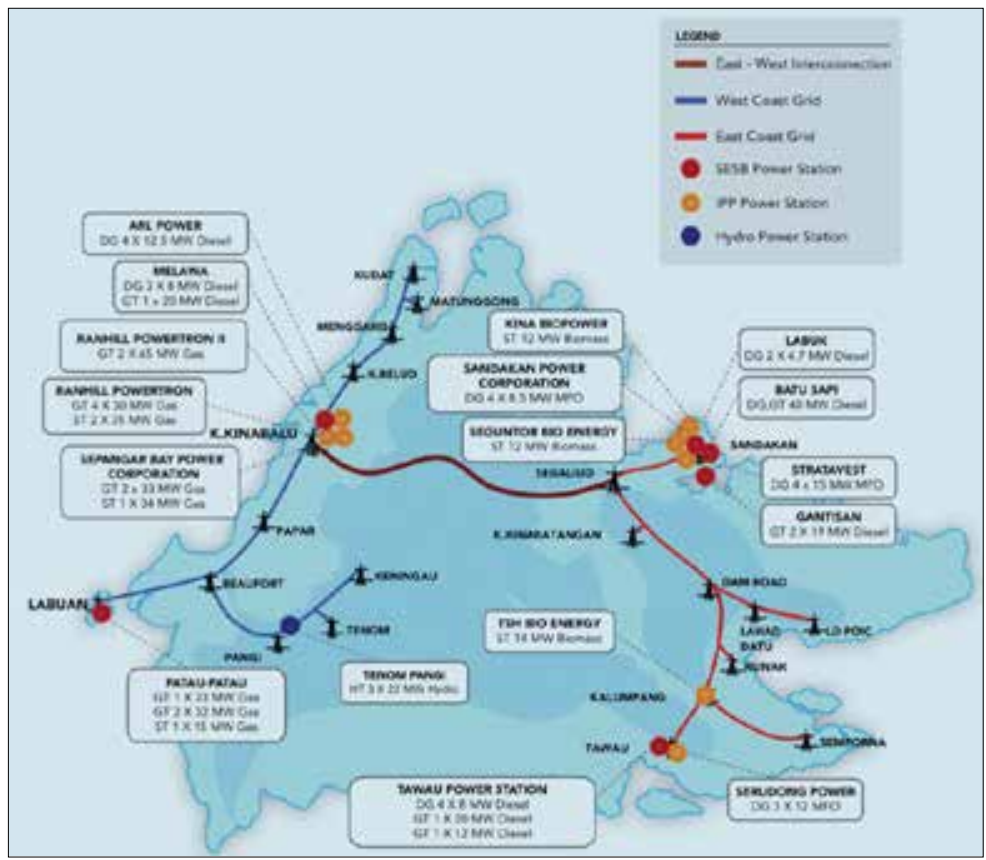

Figure 2a: Major power stations in Sabah

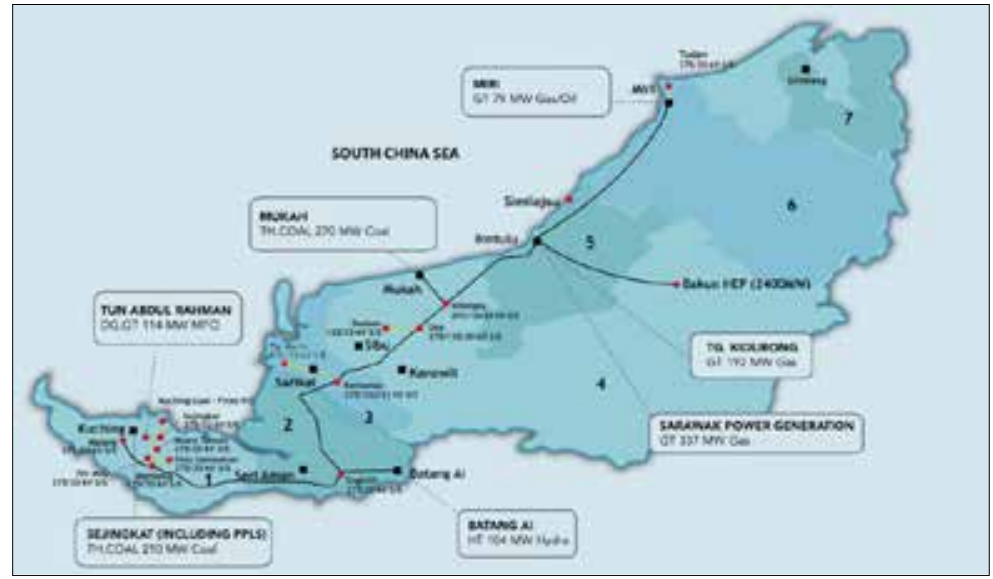

Figure 2b: Major power stations in Sarawak 


\section{Environmental Issues}

In general, fossil fuel-fired power plants are the largest source of carbon dioxide $\left(\mathrm{CO}_{2}\right)$ emissions in the world, including in Malaysia. Today, power plants produce about 30 percent of all carbon emissions. Excessive carbon emissions harm the environment and affect human health; several global environmental issues are due to carbon pollution, including increase of atmospheric temperature (global warming) and climate change. Coal plants are the top source of carbon dioxide emissions, a primary cause of global warming. The excessive production of carbon dioxide, at the same time, disrupts the multifunctional role of atmospheric air e.g. as a pollination agent, as mentioned in Qur'an, "And We have sent the fertilizing winds and sent down water from the sky" (Q. al-Hijr 15:22), to perpetuate (preserve) life especially for the production of food from plants. High carbon dioxide concentrations impede plant growth and will eventually threaten food security. ${ }^{15}$

Carbon dioxide and other greenhouse gases originally performed an important role in sustaining life on Earth. These gases acted as a thermal blanket for the planet, absorbing heat from the sun and keeping the Earth's surface warm enough to support life at an average of 15 degrees Celsius $\left({ }^{\circ} \mathrm{C}\right)$. One of the causes of global warming therefore enabled life. However, the current expansion in global warming is a serious environmental issue that threatens all life on Earth. As the Earth's atmosphere and surface are gradually heated due to trapped thermal infrared radiation (IR) that is prevented from escaping into outer space by increased greenhouse gases, the planet's surface is warmed above what it should be. ${ }^{16}$

Most climate scientists agree that human activity is the main cause of global warming, rather than natural events. ${ }^{17}$ Greenhouse gases, as listed by the United States and international inventories, are $\mathrm{CO}_{2}, \mathrm{CH}_{4}$, and $\mathrm{N}_{2} \mathrm{O}$, in addition to several groups of fluorinated gases: hydrofluorocarbons (HFCs), perfluorocarbons (PFCs), sulphur hexafluoride $\left(\mathrm{SF}_{6}\right)$, and nitrogen trifluoride $\left(\mathrm{NF}_{3}\right)$. Of the total, $\mathrm{CO}_{2}$ is the most-released greenhouse gas, contributing 82 percent $^{18}$ of all emissions in the U.S. and 76 percent ${ }^{19}$ globally, as reported by the U.S Environmental Protection Agency. 


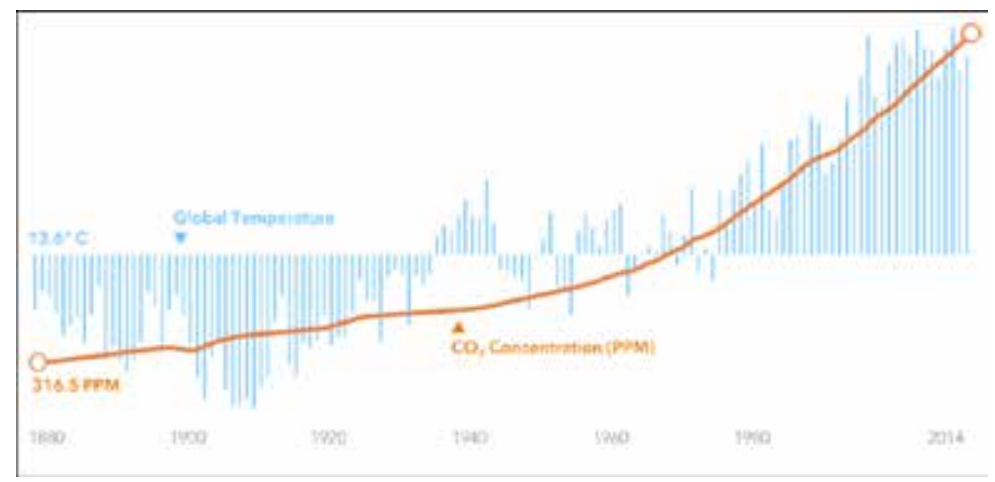

Figure 3: The changes of global temperature and carbon dioxide concentration (2014 U.S National Climate Assessment)

Figure 3 shows that the global annual average temperature, as measured over both land and oceans, has increased by more than $0.8^{\circ} \mathrm{C}$ since 1880 . The bars represent an average value taken between the years 1961 and 1990, in which $13.6^{\circ} \mathrm{C}$ represents the long-term average temperature. The line shows the increase of atmospheric carbon dioxide concentration, represented in parts per million (ppm). Right now, the world is about $1.2^{\circ} \mathrm{C}$ warmer than it was during preindustrial times. The 2016 Paris Agreement announced that the world should limit this century's global temperature increase to $1.5^{\circ} \mathrm{C}$, a stricter limit than the former goal of $2^{\circ} \mathrm{C}$. This is because just a $2^{\circ} \mathrm{C}$ increase will seriously threaten humanity's access to food, water, shelter, energy and health..$^{20}$ Consequently, as it is clear that a large amount of $\mathrm{CO}_{2}$ emissions come from fossil fuel power plants, dependency on fossil fuels can no longer be maintained within the energy sector. Rather, the quest for alternative sources of energy is crucial.

\section{Green Initiatives in Malaysia}

The transition from conventional power resources to renewable alternative energy is fundamental to Islamic-based sustainable development, as the protection of life (hifz al-nafs) and the protection of the environment (hifz al-bi' $a$ h) are predicated upon a balance between economic and social development and the environment. ${ }^{21}$ This is also in line with the Quranic principle of building the Earth ( $i$ 'mar al-ard) and also the hadith that states: "The world is green and pleasant, and God has put it under your charge to see how you will manage." As the transition from fossil fuels to renewable energies could reduce the greenhouse effect, it can be the best measure to reduce the impact of climate change. Therefore, Malaysia and other 
nations should consider expanding the use of renewable and clean resources as preparation for their future energy needs.

To that end, the Malaysian government is now working to tackle the problem of rising energy consumption by providing the MySuria solar panels scheme to those who are less fortunate. This measure aims to educate people, improve their financial situation, and address environmental issues such as excessive carbon dioxide emissions. The initiative was pioneered as a pilot programme known as 'Sunlight at Koridor Utara' (or SuriaKU) in Pauh, Perlis. It involved various sectors, including the Perlis State Government, Northern Corridor Implementation Authority (NCIA), Gading Kencana Sdn Bhd (GKSB), Energy Green Technology and the Water Ministry (KeTTHA), and the Sustainable Energy Development Authority (SEDA). After it had proven successful, the pilot programme was rebranded as MySuria, which continues to uplift the economic opportunities of B40 households.

This project allows participants to save power consumption and generate extra income by selling excess electricity to utility companies. Through this initiative, solar panels will be installed in 1,620 units to generate electricity that will be sold directly to Tenaga Nasional Berhad (TNB), with each participant being able to earn an extra monthly income of up to RM600. Moreover, the programme is expected to give long-term benefit to the targeted participants, lasting up to 21 years, through the Renewable Energy Power Purchase Agreement under the Feed-in-Tariff (FiT) mechanism. ${ }^{22}$ Under Malaysia's FiT system, the Distribution Licensees (DLs) e.g. TNB, are obliged to buy the electricity produced from renewable resources from Feed-in Approval Holders (FIAHs), or persons who hold a feed-in approval. ${ }^{23}$ Since 2017, Malaysia has also begun to implement another investment system based on renewable energy technology, known as Net Energy Metering (NEM). This also allows the self-consumption of electricity generated by solar photovoltaic systems, with excess energy being sold to utility companies. ${ }^{24}$

There is also incentive from the Malaysian government to investment in and adopt green technology. Under the Economic Transformation Programme, the government of Malaysia has provided a financing platform through Green Tech Malaysia to help new green projects get off the ground. Applications are jointly supported by participating financial institutions, including several banks in Malaysia. The scheme, called the Green Technology Financing Scheme (GTFS), is aimed at promoting green technologies that have the potential to minimise the degradation of the environment, reduce Green House Gas emissions, promote a healthy environment, conserve the use of energy and natural resources, and promote the use of renewable resources.

GTFS was originally proposed by Prime Minister Najib Razak during the tabling of the 2010 Budget with a total financing amount of RM1.5 billion. In 
2013, funds for GTFS were increased by RM2 billion with the application period being extended to 31 December 2015. During the 2016 Budget, the deadline was extended again until 31 December 2017. As stated by Green Tech Malaysia, 272 projects have benefited from this scheme between 2010 and 31 December 2016, involving RM2.962 billion of financial support. According to news released in March 2017, the Green Technology and Climate Change Council meeting chaired by Prime Minister Najib Razak has agreed to extend the fund for a further five years with an additional allocation of RM5 billion. This further extension will definitely benefit companies who produce and use green technology. This national initiative has opened up great business opportunities for the people, while also encouraging them to appreciate the environment in order to support sustainable development in Malaysia. ${ }^{25}$

\begin{tabular}{|c|c|c|c|c|c|c|}
\hline Year & Biomass & Biogass & $\begin{array}{c}\text { Small } \\
\text { hydropower }\end{array}$ & Solar & Waste & $\begin{array}{c}\text { Total } \\
\text { (MW) }\end{array}$ \\
\hline 2011 & 110 & 20 & 60 & 9 & 20 & 219 \\
\hline 2015 & 330 & 100 & 290 & 65 & 200 & 985 \\
\hline 2020 & 800 & 240 & 490 & 190 & 360 & 2,080 \\
\hline 2025 & 1,190 & 350 & 490 & 455 & 380 & 2,865 \\
\hline 2030 & 1,340 & 410 & 490 & 1,370 & 390 & 4,000 \\
\hline 2035 & 1,340 & 410 & 490 & 3,700 & 400 & 6,340 \\
\hline 2040 & 1,340 & 410 & 490 & 7,450 & 410 & 10,100 \\
\hline 2045 & 1,340 & 410 & 490 & 12,450 & 420 & 15,110 \\
\hline 2050 & 1,340 & 410 & 490 & 18,700 & 430 & 21,370 \\
\hline
\end{tabular}

Table 1: Projected Renewable Energy Growth ${ }^{26}$

Table 1 shows projected Renewable Energy (RE) growth in the run up to 2050, as estimated by the Sustainable Energy Development Authority (SEDA) Malaysia. The former Chief Executive Officer of SEDA, Datin Badriyah Ab Malek, presented the above data during the Waste Management Conference 2011 (WM2011) at the Sime Darby Convention Centre, Kuala Lumpur. ${ }^{27}$ As the adoption of energy mix in Malaysia will focus on the growth of RE resources, the number of RE power stations will need to increase. The power generation from small hydropower, biogas, and biomass stations has so far been limited to certain production levels based on capacity, with 2030 marked as their growth limit. There are only two resources, e.g. solar and waste, that will experience incremental power production each year. However, while the number of waste power stations will grow gradually, solar will witness drastic growth; it is expected to be the major RE contributor to the national grid by 2030 . 


\section{Smart Energy Strategies}

The implementation of renewable energy programs in the context of Islamic countries, especially in the Organisation of Islamic Cooperation (OIC) member states, has been limited by the amounts of crude oil and gas these states have access to Bahrain, Brunei Darussalam, Kuwait, Libya, Oman, Qatar, Saudi Arabia, Turkmenistan and the United Arab Emirates, for example, generate all their electricity from fossil fuel resources. The use of renewable energy resources e.g. biomass, biogas, hydro, solar photovoltaic, solar thermal, wind, tidal and waves, and geothermal, is therefore still not fully exploited. For this reason, longterm strategies have to be adopted to promote renewable energy technologies by taking into account the role of education, financial support, appropriate energy policies, international collaboration, and R\&D activities. ${ }^{28}$

From the author's point of view, education plays an important role in addressing both energy shortage and environmental issues. The search for alternative energy resources will be an endless journey if energy consumption is allowed to increase without implementing 'green practices'. According to Dr Shaikh Mohd Saifuddeen, a Senior Fellow from the Institute of Islamic Understanding Malaysia (IKIM), green practises can lead to more environmentally friendly and ecologically responsible decisions and lifestyles, which can help protect the environment and sustain its natural resources for current and future generations. In his presentation during the International Seminar on Islam and Green Technology 2016 at the International Institute of Advanced Islamic Studies (IAIS) Malaysia, he stated that we can have all the renewable energy and green technology we need but, without green practices, there will still be wastage. ${ }^{29}$

As citizens of a developing country, Malaysians should act responsibly by considering green practices, such as implementing energy efficiency in order to reduce the rise of energy consumption. Basically, 'energy efficiency' is the reduction of the amount of energy required to provide products and services. This is one of the best measures that we can take on our own initiative to address the issue of increasing global energy demand. Moreover, around 22 percent of Malaysia's energy consumption is from the residential and transportation sectors, which involve energy consumption by ordinary people like us. Instead of considering an alternative source of energy such as nuclear, we have the option to choose an alternative way of life that practices energy efficiency. Among energy efficiency practises, we could also consider: changing inefficient appliances with more efficient ones; reducing the loads of mechanical appliances to reduce operating energy; upgrading building insulation and roofing; developing good air ventilation via natural cooling systems; and using energy-saving control systems in electrical appliances whenever possible. This might need some upgrading 
to our homes, but the investment will definitely give positive returns without involving a large amount of cost. We can start such practices by ensuring our next purchase is of an 'energy efficient' product/equipment.

Most consumers now prefer multitasking, which is aimed at expediting work. ${ }^{30}$ They mostly prefer to complete work by using many electrical appliances that can be operated automatically, all at the same time. For example, clothes can be washed using a washing machine while biscuits are baked in an oven, floors cleaned by a vacuum cleaner, and the television and air-conditioner left on. Although multitasking looks more efficient in terms of work accomplished, the practice is not energy efficient. ${ }^{31}$ Most of the appliances used require high wattage for operation. When they are utilised simultaneously, they will cause a daily energy peak, requiring increased amounts of electricity supply from the power utility. Consequently, the utility company has to increase energy production by burning more fossil fuel. In fact, they always produce more energy (almost double) than the amount needed by consumers to ensure the continuation of electricity during peak hours. It is clear that multitasking jobs involving several high wattage appliances at a time will only increase load and is not good practice. Instead, focusing on a certain task by listing necessary work to be prioritised will help reduce total everyday energy consumption. At the same time, prioritising work will keep the consumer free from fatigue and the stress of multiple loads. ${ }^{32}$

Transportation also uses a lot of energy and causes carbon emissions. Most of the vehicles manufactured around the world are fuelled by fossil resources. The author suggests that the use of energy resources must be smart in terms of vehicle size and purpose. For lightweight vehicles, for example, such as motorcycles, cars, and all types of van, full electric power can be used. The energy shift for light vehicles from petrol to full electric is possible since there are heavier vehicles like electric buses available in the market. For some people, the use of batteries for these vehicles is costly, causing an increase in the price of the vehicle, and might not be practical for long distance travel. The author suggests that these vehicles can be sold in two 'energy storage' options: normal battery units and rental battery units. The second option is actually aimed at reducing the cost of the electric vehicle, and revolutionising the charging system by introducing a pre-charged battery-swap service. This service could expedite the 'refuelling' or charging process.

All the above strategies encourage humanity to progress in developing the Earth ( $i$ 'mar al-ard) by considering the importance of energy mix, smart energy consumption, and energy efficiency. At the same time, it involves 'green practices' and the act of moderation (wasatiyyah) so that human beings will be more responsible, avoid extravagance, preserve natural resources, reduce waste, and, most importantly, strive to sustain the balance of nature. 


\section{Feasible Future Energy in Malaysia}

In Islamic history, renewable energy resources were often utilised. Water and wind, for example, were exploited to grind grains and draw up water for irrigation and domestic purposes. The ingenious mechanical devices built by Muslim inventors to utilise these renewable resources included AlJazari's reciprocating water pump, Taqi Al-Din's six-cylinder water pump, the Persian 'saqiya' water wheel, and the Persian 'Piruz Nahavandi' vertical windmills. There were also wind towers (or wind catchers), traditional Persian architectural elements built to create natural ventilation in buildings for cooling purposes. This invention worked naturally, with the combination of both wind and water movements, and is considered an energy efficient and sustainable structure of great benefit to modern architectural design in reducing power consumption and saving energy. In the modern world, however, the approach to leverage renewable energy resources is considerably different as more focus is given to the use of current technological advancement based on electrical and electronics development.

Today the world population is very high, with energy consumption significantly greater than in previous centuries. The facilities to harness energy must be able meet this new demand. The number of power production facilities and their energy capacity must therefore grow. In Malaysia, the projected growth of renewable energy as listed in Table 1 seems able to cope with future demand. This involves the energy harnessed from the country's biomass, biogas, small hydropower, solar, and waste. However, the ambitious target contained in the above projection is mainly dependant on the soaring of solar power utilisation. Although solar power is free and available everywhere, it cannot generate electricity after sunset. To overcome this drawback, power storage is needed, such as batteries, further increasing the system's cost. This may deter the use of this system, especially as power storage is currently limited. If so, the above projections may be incorrect. Indeed, in reality the latest measures taken by the Malaysian government in addressing insufficient power supply involve increasing energy production from the fossil fuel-based power plants. ${ }^{33}$ Moreover, Malaysia's largest combined cycle gas turbine is currently under development in Alor Gajah, Melaka, and is expected to begin operation in 2021. ${ }^{34}$ This further demonstrates Malaysia's continued reliance on fossil fuels.

From the author's point of view, however, it would be far better if Malaysia started to leverage and optimise sources of clean energy. Reliance on limited sources of non-renewable energy, coupled with the absence of backup resources, will eventually lead to an energy crisis capable of negatively affecting the country's economy. Alternatively, an energy mix strategy based on renewable 
resources would be very effective in a country like Malaysia. For example, as most parts of Malaysia receive an abundant amount of solar radiation throughout the year, solar energy is a promising alternative source of electricity for the country. Solar power stations can be expanded on land and as floating systems on water, such as on reservoirs, lakes, wetlands, ponds, and canals. Also, there are many rivers flowing in most of the states in Malaysia; from high stream water flow, small hydropower stations could be built for the use of the people who live nearby when solar power is unavailable, especially at night. In fact, hydropower could provide continuous power as well. Indeed, the use of small units of hydropower is more economical than solar power, as it does not involve high capital costs. The number of small hydropower stations in Malaysia therefore needs to be increased and not allowed to remain limited, as is currently expected to be the case (Table 1).

Solar and hydropower systems could therefore complement each other in providing ample energy to Malaysia's National Grid System. These two technologies are already available in Malaysia, which has competent experts in the field capable of developing and managing the systems further. The next practical measure that can be undertaken involves the optimisation of the use of these technologies to a level that promotes energy efficiency. Several places in the world, such as Costa Rica, Orkney (Scotland, UK), Palo Alto (USA), Samsø (Denmark), and Schleswig-Holstein (Germany), have managed to satisfy 100 percent of their electricity demand with a renewable energy (RE) mix like this one. Other places have achieved at least 90 percent.

\section{Conclusion and Policy Recommendations}

Energy mix, smart energy consumption, energy efficiency, and transition to renewable energy sources are important measures to reduce and curb global environmental issues. In this case, 'green practices' and the act of moderation (wasatiyyah) must be inculcated in society, so that human beings will be more responsible, avoid extravagance, preserve natural resources, reduce waste and, most importantly, strive to sustain the balance of nature. This effort is in accordance with Islamic concerns about the corruption of the Earth, as mentioned in the Qur'an: "And desire not corruption in the land. Indeed, Allah does not like corrupters" (Q. al-Qasas 28:77). ${ }^{35}$ As khalifah (vicegerency), humanity has inherited power and responsibility to bring harmony to the planet Earth and its life forms. This article proposes several policy recommendations, as follows:

- Keep the balance of natural ecological systems. The Earth is an ideal environment for life not only because of its distance from the Sun, in the 
'habitable zone', but because its atmosphere contains greenhouse gases that keep the planet's temperature within the range suitable for living things. It is our responsibility as 'Stewards of the Earth' to take care of this environment so that its quality can be maintained. God assigned man to keep the natural balance, as mentioned in the Qur'an: "He has raised the heaven high and set up the measure, that you may not transgress the measure. So weigh all things fairly and fall not short of the balance" (Q. al-Rahman 55:5-9). ${ }^{36}$ Therefore, humankind should now consider their activities, especially those related to carbon emissions, that are in turn leading to the greenhouse effect, global warming and, finally, climate change.

- Create effective waste management systems. Industrial processes and fossil fuels are the highest contributors to carbon dioxide emissions. While both are important for worldwide development, they release too much greenhouse gas. In order to curb this issue, good waste management systems must be utilised. These will include the filtration of hazardous gases, deadly chemical compounds, and other harmful elements so that they will not escape into the open environment. Waste management systems can be included as a mandatory requirement before the approval of any carbon emissions related human activities. In Islam, avoiding waste and extravagance is necessary, as mentioned the Qur'an: "God loves not the prodigals" (Q. al-A raf 7:31). ${ }^{37}$ This is in line with the act of moderation (wasatiyyah) that encourages human beings not to allow wastage in their daily lives.

- Strong enforcement of environmental quality monitoring. The authorities must monitor the implementation of each mandatory requirement e.g. waste management systems, as mentioned above. At the same time, immediate action must also be taken before any environmental issue becomes serious. If the action is a bit late, it might result in environmental degradation, as well as financial loss. Informers can also assist the authorities and receive a special reward if their information is proven correct. A whistleblower could play an important role in revealing the identities of offenders, if there are leakages and/or corruption involving the authorities. The offenders must be sentenced to a fine or imprisoned or both. These effective actions are meant to be a lesson, not only for offenders, but also for the general populace about the importance of a healthy environment.

- Compensation to offset social losses. Most energy-based developments involve large land areas, especially in rural regions. This often involves 
the displacement of local residents. Reasonable compensation is very important for such displaced peoples, to help them continue a better life in a new area. The conpensation must also include comfortable housing units, amenities and financial support in order to facilitate the transfer of these people. In fact, Islam has underlined the principle of fair compensation between fellow human beings, the Qur'an saying: "Woe to those who deal in fraud, those who take the full measure when they receive from others, but give less when give them in measure or weight" (Q. al-Mutaffifin 83:1-3). ${ }^{38}$

- Supporting a new source of income. The source of income for most relocated villagers will be affected after they move to a new location. For example, those who previously practised fishing or agricultural activities would see their income immediately stop if the new resettlement area was either far from the sea or had no suitable land for farming. Developers are therefore encouraged to prioritise job opportunities for qualified local people. In order to increase their chances of getting a job, additional training can be conducted for less qualified people so that more of them can be absorbed into the workforce. This mechanism might be achieved by the intervention of the state government in giving support to this measure through special employment agreements in order to create more job chances for those who have been resettled.

- Transition to renewable energy. The transition to renewable energy resources is very important as we cannot keep relying on finite fossil fuels. Renewable energy is not only replenishable, but it is also free from carbon emissions and therefore environmental friendly. Most developed countries have started this transition measure from conventional to renewable power sources and, interestingly, some of the poorest countries in the world (Members of the Climate Vulnerable Forum) also aim to transition to total utilisation of renewable energy in just a few years. Malaysia could be one of these countries; the transitional plan can be included in the next budget allocation as part of the country's Transformation Plan towards a nation with developed status.

- Prioritising renewable energy sources. Currently more than 80 percent of energy production in Malaysia is based on fossil fuels. Less than 5 percent is renewable energy. Solar energy is the most suitable renewable power source for the country, since Malaysia has a consistent day duration with more than four hours of sunshine a day, on average. As the country is considering reducing oil dependency, solar power is in a position to constitute the next dominant energy resource. Thus, the implementation 
of solar power harnessing technology is highly recommended and can be included in the national renewable energy policy as one of the country's energy resources in the future.

- Benefit from being an investor in the power production sector. Malaysia has grown into one of the world's most prominent solar equipment manufacturers, being the third largest producer after the European Union and China. However, because the quality of the solar panels produced here is mostly quite high, they are used in developed countries rather than in Malaysia itself. Consequently, the carbon emissions from these companys' factories will only add to Malaysia's carbon index. Nevertheless, Malaysia can actually benefit from most of these solar manufacturing companies; We can puchase solar power equipment at a cheaper price as the cost of transportation within the country will be very low. Besides, the government can also agree to purchase a number of panels or a complete set of power systems through the production agreement and policy between the company and the country.

- Benefit from the Malaysia-China relationship. China is well known for providing cheap goods throughout the world. Recently, Malaysia has strengthened its relationship with China through cooperation and collaboration in various sectors. Most of the projects the two countries have been involved in so far have aimed at providing good infrastructure for the people in Malaysia. There is also a need, however, for a project focused on renewable energy, that could guarantee benefit, both for the people and the environment. Through the strengthened MalaysiaChina relationship, the government is in a position to request a supply of economical renewable power systems from Chinese manufacturers. China could also provide quality panels and power storage facilities at competitive prices.

- Encourage clean energy. It is not only the responsibility of utility companies to make the transition from fossil fuels to renewable power sources; it is also the responsibility of each member of society. In order to reach these individuals, the government should give encouragement by providing education, training, and support. Above all, government initiatives could be implemented to prioritise renewable energy. There are various types of small renewable power systems, such as solar power packs, available in the market that could replace conventional fossil fuel power generators. An instalment payment system can be given to rural people and small entrepreneurs to facilitate their adoption of such power packs. 
- Recognition of Green Projects. In order to further encourage companies and people to move towards green activities, recognition (e.g. certificates or awards) from the authorities can be given as a token of appreciation. Government recognition is very useful for these institutions (companies and agencies) as well as individuals as it supports their activities in the future by building public confidence. It can be proof of a standard of quality, demonstrating that their project has fulfilled green development criteria. With this recognition standard, more people will be motivated to move towards sustainable development. Consequently, efforts to inculcate sustainable practice in all human activities could be achieved.

\section{Notes}

* Shahino Mah Abdullah is a Research Fellow at the International Institute of Advanced Islamic Studies (IAIS) Malaysia. He can be contacted at shahino@ iais.org.my.

1. Thomais Vlachogianni and Athanasios Valavanidis, 'Energy and Environmental Impact on the Biosphere Energy Flow, Storage and Conversion in Human Civilization,' American Journal of Educational Research no.1 (2013): 68-78.

2. Harry J. Longwell, 'The Future of the Oil and Gas Industry: Past Approaches, New Challenges,' World Energy 5, no.3 (2002): 100-4.

3. Seppo A. Korpela, 'Oil depletion in the world,' Current Science 91, no. 9 (2006): 1148-52.

4. Li Jing, 'China's industrial growth a threat to resources,' South China Morning Post, 3 (2013): 1.

5. Mohammad Hashim Kamali, 'Environmental Care in Islam: A Quranic Perspective,' Islam and Civilisational Renewal 3, no. 2 (2012): 261-83.

6. Mohammad Hashim Kamali, The Middle Path of Moderation in Islam: The Qur'ānic Principle of Wasatiyyah (Oxford: Oxford University Press, 2015), 123.

7. United Nations Department of Economic and Social Affairs, 'World population projected to reach 9.7 billion by 2050,' United Nation. Available at: http://www. un.org/en/development/desa/news/population/2015-report.html. (Accessed on: 14 June 2017).

8. Todd Lindeman, ' 1.3 billion are living in the dark,' Washington Post, 6 Nov 2015. Available at: https://www.washingtonpost.com/graphics/world/worldwithout-power/ (Accessed on: 7 November 2017).

9. World Energy Outlook, 'Special Report: Energy Access Outlook,' (Washington: International Energy Agency, 2017), 120-44.

10. Leong Hung Yee, 'Rising cost of electricity generation,' The Star, 1 April 2017. Available at: www.thestar.com.my/business/business-news/2017/04/01/risingcost-of-electricity-generation/ (Accessed on: 14 June 2017).

11. International Energy Agency, 'World Energy Outlook 2007,'International Energy Agency USA. Available at www.iea.org/Textbase/npsum/WEO2007SUM.pdf. 
(Accessed on: 14 June 2017).

12. Richard Anderson, 'UK energy mix: Where does our power come from?' $B B C$ News, 4 December 2013. Available at: www.bbc.co.uk/news/business-24823641. (Accessed on: 14 June 2017).

13. Tick Hui Oh, Shen Yee Pang, and Shing Chyi Chua, 'Energy policy and alternative energy in Malaysia: Issues and challenges for sustainable growth,' Renewable and Sustainable Energy Reviews 14, no. 4 (2010): 1241-52.

14. Malaysia Energy Information Hub, 'Electricity Supply Industry in Malaysia: Performance and Statistical Information,' Kuala Lumpur: Energy Commission, 2017, 56.

15. Samuel S. Myers, 'Increasing CO2 threatens human nutrition,' Nature 510, no: 4, (2014): 139-42.

16. NASA Global Climate Change, 'A Blanket Around the Earth,' Nasa. Available at: http://climate.nasa.gov/causes/ (Accessed on: 19 January 2017).

17. Naomi Oreskes, 'The Scientific Consensus on Climate Change,'Science 306, no. 5702 (2004): 1686.

18. United States Environmental Protection Agency, 'Greenhouse Gas Emissions', $E P A$. Available at: https://www.epa.gov/ghgemissions/us-greenhouse-gasinventory-report-1990-2014. (Accessed on: 19 January 2016).

19. Ibid., 22.

20. Laura Geggel, 'How Would Just 2 Degrees of Warming Change the Planet?' Live Science, 29 April 2017. Available at: https:/www.livescience.com/58891-why2-degrees-celsius-increase-matters.html. (Accessed on: 12 April 2017).

21. Shahino Mah Abdullah, 'Carbon dioxide emissions causing global warming,' New Straits Times, 13 December 2017.

22. Business Times, 'SuriaKU set to go nationwide via MySuria,' New Straits Times, 22 October 2016.

23. Overview of the FiT System in Malaysia, 'Sustainable Energy Development Authority of Malaysia (SEDA Malaysia),' Available at: http://seda.gov.my/ overview_of fit_concept_in_malaysia.html. (Accessed on: 17 January 2018).

24. 'Malaysia to implement net energy metering next year,' The Star, 5 October 2016.

25. Joy Lee, 'A growing solar industry,' The Star, 19 June 2017.

26. Asia Biomass Office, 'Malaysia is Ambitiously Introducing Solar Power and Building Manufacturing Plants.' Available at: https:/www.asiabiomass.jp/ english/topics/1211_05.html. (Accessed on: 16 June 2017).

27. Badriyah Abdul Māek, 'Sustainable Energy Development Authority Malaysia 'Renewable Energy Development in Malaysia: Overview of Renewable Energy Policy: Are We On The Right Track?' Available at http://ensearch.org/wpcontent/uploads/2011/11/HERE.pdf. (Accessed on: 16 June 2017).

28. Kamaruzzaman Sopian, Baharuddin Ali and Nilofar Asim, 'Strategies for Renewable Energy Applications in the Organization of Islamic Conference (OIC) Countries,' Renewable and Sustainable Energy Reviews 15, no: 2 (2011): 4706-25.

29. Shaikh Mohd Saifuddeen, 'Green Practices and Islam: Towards Sustainability.' Available at: http://www.iais.org.my/e/attach/2016/16NOV2016_science_ seminar/keynote2.pdf. (Accessed on: 14 June 2017). 
30. Charlene M. Kalenkoski and Gigi Foster, 'Introduction: The Economics of Multitasking,' in The Economics of Multitasking, ed. Charlene M. Kalenkoski and Gigi Foster (New York: Palgrave Macmillan, 2006), 1-5.

31. Rob Waugh, 'People love multitasking - but sadly both sexes are terrible at it, not just men,' Daily Mail, 1 May 2012.

32. Lisa Quast, 'Want to Be More Productive? Stop Multi-Tasking,' Forbes, 6 February 2017.

33. S. Piarapakaran, 'Increasing the economic efficiency of coal power plants,' The Sun, 27 February 2017, 17.

34. Michael Raj, 'Malaysia's largest power plant project to begin operations in 2021,' Bernama, 12 November 2017. 